\title{
Pengaruh Struktur Kepemilikan dan Kualitas Audit terhadap Manajemen Laba
}

\author{
Elisa Putri Agustin ${ }^{1}$, Jacobus Widiatmoko ${ }^{2}$ \\ Universitas Stikubank Semarang, Indonesia \\ elisaputri954@gmail.com, jwidiatmoko@edu.unisbank.ac.id
}

*Penulis Korespondensi

Diajukan : 25 Januari 2022

Disetujui : 30 Januari 2022

Dipublikasi : 1 Februari 2022

\begin{abstract}
Earnings management influenced by company's ownership structure and audit quality. This study was made with the aim of empirically proving the effect of ownership structure (managerial ownership, institusional ownership, foreign ownership, and ownership concentration), and audit quality on earnings management, with the addition of profitability and leverage variables as control variables. This study uses quantitative research methods with secondary data collection techniques. The sample collection method in this study used a purposive sampling method with specified criteria. Secondary data for the study was taken from the annual report of manufacturing companies listed on the Indonesia Stock Exchange with the research year 2017 to 2020. The source of secondary data in this study was obtained through www.idx.co.id. This research sample counted 141 companies that meet criteria. Data processing using SPSS application. The analysis technique used is multiple linear regression analysis. Based on the results of the tests and research that have been described, it is concluded that there is a significant negative effect between the variables of institutional ownership, ownership concentration and audit quality on earnings management. Managerial ownership and foreign ownership variables have no significant effect on earnings management. Of the two control variables used in this study, only leverage has a negative effect on earnings management, while profitability does not affect earnings management. The R-Squared value of $52 \%$ can be explained by the variables contained in this study, while the remaining $48 \%$ is influenced by factors not explained in this study.
\end{abstract}

Keywords: Audit quality; Earnings management; Ownership structure; Managerial ownership; Institutional ownership; Foreign ownership; Ownership concentration; Profitability; Leverage

\section{PENDAHULUAN}

Komponen laporan keuangan yang menjadi perhatian utama dalam pengambilan keputusan salah satunya adalah laporan laba rugi dan penghasilan komprehensif lain. Besarnya pengaruh terhadap informasi laba perusahaan yang di sajikan dalam laporan keuangan menjadikan laba menjadi sangat riskan untuk di kendalikan atau di intervensi. Pihak manajemen sebagai pengelola dan penanggung jawab atas semua kegiatan operasional perusahaan dapat menggunakan wewenangnya untuk mempengaruhi pencatatan keuangan, terutama dalam mengendalikan laba yang disajikan dalam laporan keuangan, perilaku ini dapat disebut sebagai praktik manajemen laba. Manajemen laba merupakan suatu mekanisme untuk menaikan atau menurunkan laba sebelum laporan keuangan dilaporkan yang bertujuan memaksimalkan kepentingan manajemen (Felicya \& Sutrisno, 2020). Perusahaan yang menggunakan kebijakan pencatatan akrual pada laporan keuangannya sangat riskan mengalami manipulasi pencatatan akuntansi. Pencatatan akrual memudahkan manajemen untuk mempermainkan komponen-komponen akrual tanpa harus disertai dengan aktivitas penerimaan kas masuk dan penerimaan kas keluar (Sulistyanto, 2018: 16).

Fenomena manajemen laba sering dijumpai pada perusahaan besar yang terdapat di pasar modal. Salah satu kasus manajemen laba di Indonesia pernah terjadi dilakukan oleh PT Garuda Indonesia (persero) pada tahun 2018. Perusahaan GIAA melakukan manipulasi laporan keuangan 
dengan mencatatkan laba bersih kerjasama antara Garuda dan PT Mahata Aero Terknologi dengan nilai sekitar Rp. 3,48 triliun. Dana itu seharusnya masih menjadi piutang dengan kontrak yang berlaku untuk 15 tahun ke depan, namun dana ini sudah dibukukan pada tahun pertama dengan mengakui dana itu sebagai pendapatan dan masuk dalam pendapatan lain-lain. Karena hal itu perusahaan yang seharusnya merugi kemudian menghasilkan laba pada laporan keuangannya. Dua komisaris GIAA selaku pemegang saham Garuda Indonesia dengan kepemilikan sebesar 25,61 persen menolak menandatangani laporan keuangan 2018. Terdapat selisih dalam laporan keuangan GIAA pada tahun 2018 dimana perusahaan melaporkan laba pada awalnya setara Rp 72,5 miliar namun setelah diaudit kembali dan dilakukan penyesuaian pencatatan akhirnya GIAA mencatatkan kerugian setara Rp 2,53 triliun (Cnnindonesia.com).

Menurut Maswadeh (2018) struktur kepemilikan merupakan salah satu mekanisme GCG untuk mengurangi kemampuan manajemen dalam bertindak opportunistic. Obaidat (2018) mengklasifikasikan struktur kepemilikan menjadi kepemilikan manajerial, kepemilikan institusional, kepemilikan asing, dan konsentrasi kepemilikan. Struktur kepemilikan menujukkan besarnya jumlah kepemilikan saham oleh suatu pihak dalam perusahaan. Adanya kepemilikan saham yang dominan akan mensejajarkan pemegang saham dengan pihak manajemen, hal ini akan mengurangi terjadinya konflik agensi dan mengurangi ketimpangan informasi (Asymetry information). Mardianto, (2020), Nguyen et al., (2021), dan Piosik \& Genge (2019) menyatakan bahwa struktur kepemilikan berpengaruh terhadap manajemen laba. Sedangkan Felicya \& Sutrisno (2020) dan Wati \& Gultom (2021) menyatakan bahwa struktur kepemilikan tidak berpengaruh terhadap manajemen laba.

Kesempatan manajemen dalam merekayasa laba dapat diminimalisir dengan meningkatkan pengawasan perusahaan melalui auditor independen. Kehadiran auditor yang berkualitas dalam perusahaan dapat bertindak sebagai mekanisme pemantauan yang kuat bagi manajemen dan berfungsi untuk menyampaikan sinyal positif ke pasar. Auditor yang berkualitas juga dianggap memainkan peran penting dalam mengurangi konflik keagenan. Pelaporan keuangan yang andal yang dijamin oleh auditor yang berkualitas dapat meningkatkan akuntabilitas manajemen dan menjadi alat yang efektif bagi pemegang saham untuk memantau tugas manajemen (Indarti \& Widiatmoko, 2021). Kualitas auditor dapat diukur menggunakan ukuran KAP. Ukuran KAP menujukkan sikap auditor yang independen dan professional sehingga meminimalisir pihak manajemen untuk mengintervensi pendapat dan opini auditor (Natalia dkk., 2017). Hasil penelitian yang dilakukan oleh Hadi \& Tifani, (2020) menyatakan bahwa kualitas audit berpengaruh negatif terhadap manajemen laba. Albert \& Widyastuti, (2019), dan Tarigan \& Saragih (2020) menyatakan bahwa kualitas audit berpengaruh positif terhadap manajemen laba. Sedangkan Wijayanti dkk., (2021) dan Natalia dkk., (2017) menyatakan bahwa kualitas audit tidak berpengaruh terhadap manajemen laba.

Adanya perbedaan dari hasil peneliti-peneliti sebelumnya membuat peneliti tertarik untuk melakukan penelitian ini untuk membuktikan bukti empiris serta menyempurnakan teori penelitian yang ada. Penelitian ini dilakukan dengan tujuan untuk membuktikan secara empiris pengaruh struktur kepemilikan meliputi, kepemilikan manajerial, kepemilikan institusional, kepemilikan asing, konsentrasi kepemilikan, dan kualitas audit terhadap manajemen laba dengan penambahan variabel profitabilitas dan leverage sebagai variabel kontrol. Diharapkan penelitian ini dapat memberikan kontribusi bagi peneliti-peneliti selanjutnya serta menambah pengetahuan bagi pihak manajemen perusahaan dan investor mengenai variabel yang terdapat dalam penelitian ini.

\section{STUDI LITERATUR \\ Pengaruh kepemilikan manajerial terhadap manajemen laba}

Kepemilikan manajerial memberi kewenangan bagi dewan direksi dan pihak manajemen untuk mengelola perusahaan (Hasty \& Herawaty, 2017). Teori keagenan menimbulkan konflik kepentingan antar pemegang saham dengan pihak manajemen sehingga mempengaruhi motivasi manajemen laba (Dwijayanti \& Suryanawa, 2017). Dengan adanya kepemilikan saham manajerial diharapkan dapat mengurangi konflik keagenan dan mensejajarkan kepentingan pihak manajemen dengan pemilik saham (Giovani, 2017). Adanya kepemilikan saham manajerial membuat pihak manajemen berhati-hati dalam pengambilan keputusan karena ikut menanggung kerugian yang 
ditimbulkan dari keputusan oportunistic. Penelitian sebelumnya yang dilakukan oleh Antari dkk., (2021) menyatakan bahwa kepemilikan manajerial berpengaruh negatif signifikan terhadap manajemen laba. Semakin tinggi kepemilikan manajerial, maka semakin rendah tingkat manajemen laba.

\section{H1: Kepemilikan manajerial berpengaruh negatif terhadap Manajemen Laba}

\section{Pengaruh kepemilikan institusional terhadap manajemen laba}

Kepemilikan institusional ditandai dengan jumlah saham yang dimiliki oleh institusi, lembaga seperti bank, perusahaan asuransi, perusahaan investasi, dan pihak institusi lainnya (Damayanti \& Kusumaningtias, 2018). Semakin besar tingkat kepemilikan institusional dapat menurunkan tingkat manajemen laba karena pihak institusi terlibat langsung dalam pengambilan keputusan strategis perusahaan. kepemilikan institusional mencegah pihak manajemen untuk melakukan rekaysa laba dengan mengatur pihak manjemen melalui proses monitoring yang efektif (Giovani, 2017). Semakin besar kepemilikan institusional dalam perusahaan, semakin menunjukkan besarnya jumlah saham yang dimiliki oleh pihak institusi yang dapat berguna dalam mengurangi tindakan oportunistik manajemen (Widiatmoko et al., 2020). Felicya \& Sutrisno (2020) berpendapat bahwa investor institusi adalah sophisticated investor yang mampu melakukan monitoring terhadap tindakan manipulasi yang dilakukan manajemen sehingga mereka tidak mudah diperdaya oleh pihak manajemen.

\section{H2: Kepemilikan Institusional berpengaruh negatif terhadap Manajemen laba}

\section{Pengaruh kepemilikan asing terhadap manajemen laba}

Kepemilikan asing merupakan jumlah kepemilikan saham oleh pihak asing institusional maupun individu (Laksmi, et al., 2018). Pengetahuan akuntansi dan tata kelola perusahaan yang dimiliki investor asing dapat digunakan sebagai system pengawasan yang bagus untuk diterapkan dalam meminimalisir manajemen laba oleh pihak manajemen. Pemilik asing tertarik pada pengungkapan dan praktik keuangan yang memiliki kualitas serta performa baik sehingga mendorong manajemen meningkatkan kualitas pelaporan keuangan (Maswadeh, 2018). Semakin kecil kepemilikan asing, semakin besar motivasi manajer melakukan manajemen laba (Nguyen et al., 2021).

\section{H3: Kepemilikan asing berpengaruh negatif terhadap Manajemen Laba}

\section{Pengaruh konsentrasi kepemilikan terhadap manajemen laba}

Kepemilikan saham yang terkonsentrasi memicu munculnya perbedaan kepentingan antara pemegang saham dan memunculkan konflik keagenan, dikarenakan konsentrasi kepemilikan saham yang rendah pada suatu perusahaan mengakibatkan tingginya konflik keagenan (Widiatmoko \& Indarti, 2018). Konsentrasi kepemilikan diukur dengan jumlah pemegang saham yang dominan pada perusahaan (Amalia \& Didik, 2017). Semakin tinggi konsentrasi kepemilikan, maka kemungkinan untuk melakukan manipulasi laporan keuangan semakin rendah. Pernyataan ini didukung oleh penelitian yang dilakukan oleh Mardianto (2020) yang menyatakan konsentrasi kepemilikan mempunyai pengaruh negatif signifikan terhadap manajemen laba.

\section{H4: Terdapat pengaruh negatif konsentrasi kepemilikan terhadap manajemen laba}

\section{Pengaruh kualitas audit terhadap manajemen laba}

Kualitas audit mampu menjadi alat pendeteksi eksternal terhadap manipulasi laporan keuangan yang dilakukan manajemen perusahaan. KAP big four dikatakan lebih ahli dalam mendeteksi kecurangan pada laporan keuangan dibandigkan KAP non big four (Hasty \& Herawaty, 2017). KAP yang berkualitas serta sikap independensi auditor dapat menjadi bahan pertimbangan bagi manajemen untuk melakukan tindak oportunis karena sewaktu-waktu tindakannya akan terbongkar oleh auditor eksternal dan menimbulkan permasalahan. Susanti \& Margareta (2019) menyatakan bahwa kualitas audit mempunyai pengaruh negatif signifikan terhadap manajemen laba.

H5: Terdapat pengaruh negatif kualitas audit terhadap manajemen laba 


\section{METODE}

Penelitian ini menggunakan metode penelitian kuantitatif dengan teknik pengumpulan data sekunder. Penelitian ini bertujuan untuk mengetahui pengaruh struktur kepemilikan dan kualitas audit terhadap manajemen laba. Penelitian ini juga menambahkan variabel kontrol profitabilitas dan leverage. Struktur kepemilikan yang digunakan meliputi: kepemilikan manajerial, kepemilikan institusional, kepemilikan asing dan konsentrasi kepemilikan. Sedangkan kualitas audit di ukur menggunakan variabel dummy ukuran KAP. Manajemen laba yang digunakan adalah manajemen laba akrual yang di proksikan dengan discreditionary accrual (DA). Metode pengumpulan sampel dalam penelitian ini menggunakan metode purposive sampling dengan kriteria yang ditentukan. Data sekunder untuk penelitian diambil dari annual report perusahaan manufaktur yang terdaftar di BEI dengan tahun penelitian 2017 sampai 2020. Sumber data sekunder dalam penelitian ini diperoleh melalui www.idx.co.id dan diolah menggunakan bantuan aplikasi SPSS untuk menguji statistik deskriptif, uji asumsi klasik, analisis regresi linier berganda, uji koefisien determinasi, uji $\mathrm{F}$ (simultan), dan uji t (parsial).

Tabel 1. Kriteria sampel penelitian

\begin{tabular}{|c|c|c|c|c|c|c|}
\hline No & Keterangan & 2017 & 2018 & 2019 & 2020 & Jumlah \\
\hline 1 & $\begin{array}{l}\text { Populasi: } \\
\text { Perusahaan manufaktur yang terdaftar di BEI } \\
\text { tahun } 2017 \text { sampai } 2020\end{array}$ & 158 & 168 & 181 & 195 & 702 \\
\hline 2 & $\begin{array}{l}\text { Sampel: } \\
\text { a. Perusahaan yang tidak mengalami laba } \\
\text { b. Perusahaan yang tidak memiliki data lengkap }\end{array}$ & $\begin{array}{l}(37) \\
(87)\end{array}$ & $\begin{array}{l}(34) \\
(96)\end{array}$ & $\begin{array}{l}(35) \\
(111)\end{array}$ & $\begin{array}{l}(60) \\
(101)\end{array}$ & $\begin{array}{l}(166) \\
(395)\end{array}$ \\
\hline 3 & Jumlah sampel observasi tahun 2017-2020 & 34 & 38 & 35 & 34 & 141 \\
\hline
\end{tabular}

Sumber: Olah data idx, 2022

Tabel 2. Definisi Operasional dan Pengukuran Variabel

\begin{tabular}{|c|c|c|c|}
\hline No & Variabel & Definisi Operasional & Pengukuran variabel \\
\hline 1 & $\begin{array}{l}\text { Manajemen } \\
\text { laba }\end{array}$ & $\begin{array}{l}\text { Manajemen laba adalah } \\
\text { perilaku manajer untuk } \\
\text { mengelola laba } \\
\text { menggunakan metode } \\
\text { tertentu (Hasty \& Herawaty, } \\
\text { 2017) }\end{array}$ & $\begin{array}{l}\text { Mengguanakan Model Jones Modified } \\
\text { dengan discretionary accruals }= \\
\mathrm{TAC}=\mathrm{NI}_{\mathrm{it}}-\mathrm{CFO}_{\mathrm{it}} \\
\mathrm{TAC}_{\mathrm{t}} / \mathrm{TA}_{\mathrm{t}-1}=\beta_{1}\left(1 / \mathrm{TA}_{\mathrm{t}-1}\right)+\beta_{2}\left(\Delta \mathrm{REV}_{\mathrm{t}} /\right. \\
\left.\mathrm{TA}_{\mathrm{t}-1}\right)+\beta_{3}\left(\mathrm{PPE}_{\mathrm{t}} / \mathrm{TA}_{\mathrm{t}-1}\right)+\mathrm{e} \\
\mathrm{NDA}_{\mathrm{t}}=\alpha_{1}\left(1 / \mathrm{TA}_{\mathrm{t}-1}\right)+\alpha_{2}\left(\Delta \mathrm{REV}_{\mathrm{t}}-\right. \\
\left.\Delta \mathrm{REC}_{\mathrm{t}} / \mathrm{TA}_{\mathrm{t}-1}\right)+\alpha_{3}\left(\mathrm{PPE}_{\mathrm{t}} / \mathrm{TA}_{\mathrm{t}-1}\right) \\
\mathrm{DAC}_{\mathrm{t}}=\left(\mathrm{TAC}_{\mathrm{t}} / \mathrm{TA}_{\mathrm{t}-1}\right)-\mathrm{NDA}_{\mathrm{t}} \\
(\text { Giovani, 2017) }\end{array}$ \\
\hline 2 & $\begin{array}{l}\text { Kepemilikan } \\
\text { manajerial }\end{array}$ & $\begin{array}{l}\text { Kepemilikan manajerial } \\
\text { adalah jumlah saham yang } \\
\text { dimiliki manajer dari total } \\
\text { keseluruhan saham } \\
\text { (Widiastuti et al., 2018) }\end{array}$ & $\begin{array}{l}\mathrm{KM}=\frac{\sum \text { saham manajerial }}{\sum \text { saham beredar }} \\
\text { (Widiatmoko et al., 2020) }\end{array}$ \\
\hline 3 & $\begin{array}{l}\text { Kepemilikan } \\
\text { institusional }\end{array}$ & $\begin{array}{l}\text { Kepemilikan institusional } \\
\text { adalah kepemilikan } \\
\text { pemegang saham pada suatu } \\
\text { perusahaan yang terdiri dari } \\
\text { institusi atau Lembaga } \\
\text { (Mardianto, 2020) }\end{array}$ & $\begin{array}{l}\mathrm{KI}=\frac{\sum \text { saham institusional }}{\sum \text { saham beredar }} \\
\text { (Yovianti \& Dermawan, 2020) }\end{array}$ \\
\hline
\end{tabular}


Owner: Riset \& Jurnal Akuntansi

e-ISSN : 2548-9224 |p-ISSN : 2548-7507

Volume 6 Nomor 1, Januari 2022

DOI : https://doi.org/10.33395/owner.v6i1.707

\begin{tabular}{|c|c|c|c|}
\hline 4 & $\begin{array}{l}\text { Kepemilikan } \\
\text { asing }\end{array}$ & $\begin{array}{l}\text { Kepemilikan asing adalah } \\
\text { kepemilikan saham } \\
\text { perusahaan oleh investor } \\
\text { asing dari luar negeri } \\
\text { (Nguyen et al., 2021) }\end{array}$ & $\begin{array}{l}\mathrm{KA}=\frac{\sum \text { saham pihak asing }}{\sum \text { saham beredar }} \\
\text { (Nguyen et al., 2021) }\end{array}$ \\
\hline 5 & $\begin{array}{l}\text { Konsentrasi } \\
\text { kepemilikan }\end{array}$ & $\begin{array}{l}\text { Konsentrasi kepemilikan } \\
\text { adalah kepemilikan saham } \\
\text { diukur dengan presentase } \\
\text { kepemilikan saham dari } \\
\text { Sebagian perorangan atau } \\
\text { kelompok (Mardianto, 2020). }\end{array}$ & $\begin{array}{l}\mathrm{KK}=\frac{\sum \text { saham kepemilikan terbesar }}{\sum \text { saham beredar }} \\
\text { (Indarti \& Widiatmoko, 2021) }\end{array}$ \\
\hline 6 & $\begin{array}{l}\text { Kualitas } \\
\text { audit }\end{array}$ & $\begin{array}{l}\text { KAP yang digunakan } \\
\text { perusahaan untuk mengaudit } \\
\text { laporan keuangan. } \\
\text { (Albert \& Widyastuti, 2019) }\end{array}$ & $\begin{array}{l}\text { Nilai } 1 \text { untuk KAP big four, nilai } 0 \text { untuk } \\
\text { KAP big non four } \\
\text { (Albert \& Widyastuti, 2019) }\end{array}$ \\
\hline 7 & Profitabilitas & $\begin{array}{l}\text { Profitabilitas adalah } \\
\text { kemampuan perusahaan } \\
\text { dalam menghasilkan labanya } \\
\text { (Giovani, 2017) }\end{array}$ & $\begin{array}{l}\mathrm{ROA}=\frac{\text { Laba bersih setelah pajak }}{\sum \text { Aset }} \\
\text { (yovianti \& dermawan, 2020) }\end{array}$ \\
\hline 8 & Leverage & $\begin{array}{l}\text { Leverage menunjukkan } \\
\text { sumber dana operasi } \\
\text { perusahaan (Yovianti \& } \\
\text { Dermawan, 2020) }\end{array}$ & $\begin{array}{l}\text { Leverage }=\frac{\sum \text { Hutang }}{\sum \text { Aset }} \\
\text { (Yovianti \& Dermawan, 2020) }\end{array}$ \\
\hline
\end{tabular}

Sumber: Jurnal publikasi sinta \& google schoolar

HASIL

Statistik deskriptif

Tabel 3. Statistik deskriptif

\begin{tabular}{lccccc}
\hline & N & Minimum & Maximum & Mean & Std. Deviation \\
\hline KM & 141 & 0,00 & 0,92 & 0,1623 & 0,25142 \\
KI & 141 & 0,00 & 0,97 & 0,5426 & 0,32214 \\
KA & 141 & 0,00 & 0,93 & 0,2639 & 0,28435 \\
KK & 141 & 0,10 & 0,92 & 0,4924 & 0,21716 \\
EM & 141 & $-0,47$ & 0,80 & $-0,0324$ & 0,10223 \\
ROA & 141 & 0,00 & 0,76 & 0,0627 & 0,07836 \\
LEV & 141 & 0,00 & 0,66 & 0,1044 & 0,8965 \\
Valid N & 141 & & & & \\
(listwise) & & & & & \\
\hline
\end{tabular}

Sumber: Olah data SPSS, 2022

Tabel 4. Kualitas audit

\begin{tabular}{clcc}
\hline No & \multicolumn{1}{c}{ keterangan } & frekuensi & presentase \\
\hline 1 & Big four & 47 & $33,33 \%$ \\
2 & Non big four & 94 & $66,67 \%$ \\
3 & jumlah & 141 & $100 \%$ \\
\hline
\end{tabular}

Sumber: Data diolah, 2022

Berdasarkan hasil output data sekunder pada tabel 3 menunjukkan hasil statistik deskriptif dari masing-masing variabel penelitian meliputi jumlah penelitian, nilai minimum, nilai maksimum, nilai rata-rata, dan nilai standar deviasi. Variabel kepemilikan manajerial (KM) memiliki nilai minimum sebesar 0.00003193 yang terdapat pada perusahaan Charoen Pokphand Indonesia Tbk 2017. Nilai maksimum sebesar 0.92 yang terdapat pada perusahaan Eratex Djaja Tbk 2018. 
Variabel kepemilikan institusional (KI) memiliki nilai minimum sebesar 0.000277 yang terdapat pada perusahaan Betonjaya Manunggal Tbk 2020. Nilai maksimum sebesar 0.97 yang terdapat pada perusahaan Mulia Industrindo Tbk 2019. Variabel kepemilikan asing (KA) memiliki nilai minimum sebesar 0.000055 yang terdapat pada perusahaan Betonjaya Manunggal Tbk 2020. Nilai maksimum sebesar 0.93 yang terdapat pada perusahaan Lion Metal Works Tbk 2019.Variabel konsentrasi kepemilikan (KK) memiliki nilai minimum sebesar 0.10 yang terdapat pada perusahaan Kalbe Farma Tbk 2018. Nilai maksimum sebesar 0.92 yang terdapat pada perusahaan Eratex Djaja Tbk 2018. Dilihat pada tabel 4 menunjukkan variabel audit (KUA) yang diukur menggunakan variabel dummy memiliki nilai sebesar 33,33\% untuk jumlah perusahaan yang diaudit oleh KAP big four pada 47 sampel perusahaan, nilai sebesar 66,67\% untuk jumlah perusahaan yang tidak diaudit oleh KAP big four pada 94 sampel perusahaan. Variabel kepemilikan manajerial, kepemilikan asing, manajemen laba, dan profitabilitas memiliki distribusi data yang merata karena lebih besar dari mean, artinya tidak terjadi perbedaan jauh antara data satu dengan data lainnya. Variabel kepemilikan institusional, konsentrasi kepemilikan, dan leverage memiliki distribusi data yang tidak merata karena lebih kecil dari mean, artinya terjadi perbedaan jauh antara data satu dengan data lainnya.

\section{Uji asumsi klasik}

\section{Uji normalitas}

Tabel 5. Uji Normalitas

\begin{tabular}{cccc}
\hline \multicolumn{2}{c}{ Skewness } & \multicolumn{2}{c}{ Kurtosis } \\
\hline Statistic & Std. Error & Statistic & Std. Error \\
0,402 & 0,206 & 0,595 & 0,142 \\
\hline
\end{tabular}

Sumber: Olah data SPSS, 2022

Hasil uji Normalitas pada tabel 5 menunjukkan hasil bahwa nilai dari Zskewness sebesar $0,402 / 0,206=1,951$ dan Zkurtosis sebesar 0,595/0,412 = 1,444. Masing-masing nilai kurang dari 1,96. Disimpulkan bahwa data yang diolah memenuhi syarat normalitas.

\section{Uji Heteroskedestisitas}

Tabel 6. Uji Heteroskedestisitas metode Glejser

\begin{tabular}{clccccc}
\hline \multirow{2}{*}{ Model } & \multicolumn{2}{c}{$\begin{array}{c}\text { Unstandarized } \\
\text { Coefficients }\end{array}$} & $\begin{array}{c}\text { Standarized } \\
\text { Coefficients }\end{array}$ & t & \multirow{2}{*}{ Sig. } \\
\cline { 3 - 5 } & \multicolumn{2}{c}{ B } & Std. Error & Beta & & \\
\hline & KM & 0,027 & 0,024 & & 1,106 & 0,271 \\
& & 0,015 & 0,034 & 0,044 & 0,457 & 0,648 \\
& KI & 0,008 & 0,025 & 0,029 & 0,311 & 0,756 \\
& KA & $-0,012$ & 0,028 & $-0,040$ & $-0,444$ & 0,658 \\
& KK & 0,001 & 0,035 & 0,001 & 0,015 & 0,988 \\
& KUA & 0,002 & 0,016 & 0,011 & 0,120 & 0,904 \\
& ROA & $-0,070$ & 0,094 & $-0,063$ & $-0,740$ & 0,461 \\
& LEV & 0,336 & 0,083 & 0,345 & 0,165 & 0,890 \\
\hline
\end{tabular}

Sumber: Olah Data SPSS,2022

Hasil uji heteroskedestisitas pada tabel 6 menujukkan nilai probabilitas signifikansi dari masing-masing variabel diatas dengan tingkat kepercayaan $\geq 0,05$ yang berarti tidak terjadi gejala heteroskedastisitas pada residual dalam penelitian ini.

\section{Uji Multikolinieritas}

Tabel 7. Uji Mutikolinearitas dengan korelasi

\begin{tabular}{|c|c|c|c|}
\hline Variabel & Tolerance & VIF & Kesimpulan \\
\hline KM & 0,685 & 1,460 & Tidak terjadi \\
\hline KI & 0,757 & 1,321 & Tidak terjadi \\
\hline KA & 0,802 & 1,247 & Tidak terjadi \\
\hline
\end{tabular}


Owner: Riset \& Jurnal Akuntansi

e-ISSN : 2548-9224 |p-ISSN : 2548-7507

Volume 6 Nomor 1, Januari 2022

$\begin{array}{llll}\text { KK } & 0,838 & 1,194 & \text { Tidak terjadi } \\ \text { KUA } & 0,837 & 1,194 & \text { Tidak terjadi } \\ \text { ROA } & 0,902 & 1,109 & \text { Tidak terjadi } \\ \text { LEV } & 0,895 & 1,117 & \text { Tidak terjadi }\end{array}$

Sumber: Olah Data SPSS, 2022

Dapat di lihat pada Tabel 7 bahwa nilai tolerance masing-masing variabel berada di atas 0,10 dan nilai (VIF) Variance Inflation Factor di bawah 10. Sehingga variabel independen dalam penelitian memenuhi tidak adanya gejala multikolinearitas.

\section{Uji Autokorelasi}

Tabel 8. Uji Autokorelasi dengan Durbin Watson

\begin{tabular}{cccccc}
\hline Model & $\mathrm{R}$ & $\mathrm{R}$ Square & $\begin{array}{c}\text { Adjusted } \mathrm{R} \\
\text { Square }\end{array}$ & $\begin{array}{c}\text { Std. Error of the } \\
\text { Estimate }\end{array}$ & Durbin-Watson \\
\hline 1 & $0,374^{\mathrm{a}}$ & 0,140 & 0,095 & 0,08306 & 2,012 \\
\hline
\end{tabular}

Sumber: Olah data SPSS, 2022

Berdasarkan tabel 8 nilai dari statistik Durbin-Watson menunjukkan angka 2.012. Dapat diketahui bahwa nilai Durbin-Watson yang diperoleh berada diantara nilai dU 1.80817 dan 4-dU dengan hasil 2,19183. Nilai dU sebesar 1,80817 dan nilai dL sebesar 1,37186, sehingga nilai Durbin-Watson berada diantara dU dan 4-dU. Dapat disimpulkan bahwa dU < DW < 4-dU atau $1,80817<2,012<2,19183$. Hal tersebut menunjukkan tidak adanya autokorelasi.

\section{Analisis Regresi Linear Berganda}

Tabel 9. Analisis Regresi Linear Berganda

\begin{tabular}{llccccc}
\hline \multirow{2}{*}{ Model } & \multicolumn{2}{c}{$\begin{array}{c}\text { Unstandarized } \\
\text { Coefficients }\end{array}$} & \multicolumn{2}{c}{$\begin{array}{c}\text { Standarized } \\
\text { Coefficients }\end{array}$} & t & Sig. \\
\cline { 3 - 5 } & & B & Std. Error & Beta & & \\
\cline { 2 - 5 } & (constant) & $-0,092$ & 0,028 & & $-3,309$ & 0,001 \\
KM & 0,14 & 0,39 & $-0,034$ & 0,357 & 0,721 \\
& KI & $-0,017$ & 0,029 & 0,054 & $-2,595$ & 0,035 \\
1 & KA & 0,007 & 0,032 & 0,018 & 0,209 & 0,834 \\
& KK & $-0,004$ & 0,040 & $-0,008$ & $-3,099$ & 0,017 \\
& KUA & $-0,020$ & 0,019 & $-0,091$ & $-3,606$ & 0,021 \\
& ROA & 0,157 & 0,108 & 0,120 & $-1,455$ & 0,148 \\
& LEV & 0,478 & 0,095 & 0,419 & 5,041 & 0,000 \\
\hline
\end{tabular}

Sumber: Olah Data Spss,2022

Berdasarkan pengolahan data pada Tabel 9, menghasilkan persamaan regresi linear berganda, sebagai berikut:

$\mathrm{Y}=-0,092+0,014 \mathrm{KM}-0,017 \mathrm{KI}+0,007 \mathrm{KA}-0,004 \mathrm{KK}-0,020 \mathrm{KUA}+0,157 \mathrm{ROA}+0,478$

$\mathrm{LEV}+\mathrm{e}$

Uji Model Penelitian

Koefisien determinasi $\left(\mathbf{R}^{2}\right)$

Tabel 10. Analisis Koefisien Determinasi

\begin{tabular}{ccccc}
\hline Model & $\mathrm{R}$ & $\mathrm{R}$ Square & Adjusted R Square & Std. Error of the Estimate \\
\hline 1 & $0,721^{\mathrm{a}}$ & 0,520 & 0,513 & 0,09512 \\
\hline
\end{tabular}

Sumber: Olah Data SPSS,2022

Berdasarkan Tabel 10, diketahui bahwa nilai R-Squared sebesar 0,52 stau sebesar 52\%. Nilai tersebut dapat diinterpretasikan bahwa variabel dependen manajemen laba dapat dijelaskan oleh 
variabel independen yang terdiri dari: kepemilikan manajerial, kepemilikan institusional, kepemilikan asing, konsentrasi kepemilikan, kualitas audit serta variabel kontrol meliputi profitabilitas dan leverage sebesar 52\%. Sisanya sebesar $48 \%$ dipengaruhi oleh faktor-faktor lain yang tidak dijelaskan dalam penelitian ini.

\section{Uji F (Simultan)}

Tabel 11. Analisis Uji F

\begin{tabular}{llccccc}
\hline & Model & Sum of Squares & df & Mean Square & F & Sig. \\
\hline 1 & Regression & 0,260 & 7 & 0,037 & 4,102 & $0,000^{\mathrm{b}}$ \\
& Residual & 1,203 & 133 & 0,009 & & \\
& Total & 1,453 & 140 & & & \\
\hline
\end{tabular}

Sumber: Olah Data SPSS,2022

Berdasarkan hasil pengujian pada tabel 11 maka dapat diketahui nilai tingkat signifikansi sebesar $0.000<0,05$ dengan nilai $\mathrm{F}$ hitung sebesar 4.102 yang berarti $\mathrm{H} 0$ ditolak dan $\mathrm{H} 1$ diterima. Dapat disimpulkan bahwa variabel independen kepemilikan manajerial, kepemilikan institusional, kepemilikan asing, konsentrasi kepemilikan, kualitas audit serta variabel kontrol profitabilitas dan leverage secara simultan atau bersama-sama berpengaruh terhadap variabel terikat manajemen laba (Y).

\section{Uji Hipotesis (Uji t parsial)}

\begin{tabular}{clccccc}
\multicolumn{7}{c}{ Tabel 12. Uji Hipotesis parsial (Uji t) } \\
\hline \multirow{2}{*}{ Model } & \multicolumn{2}{c}{$\begin{array}{c}\text { Unstandarized } \\
\text { Coefficients }\end{array}$} & $\begin{array}{c}\text { Standarized } \\
\text { Coefficients }\end{array}$ & t & Sig. \\
\cline { 3 - 5 } & \multicolumn{1}{c}{ B } & Std. Error & Beta & & \\
\hline & KM & $-0,092$ & 0,028 & & $-3,309$ & 0,001 \\
& KI & 0,14 & 0,39 & $-0,034$ & 0,357 & 0,721 \\
& KA & $-0,017$ & 0,029 & 0,054 & $-2,595$ & 0,035 \\
1 & KK & 0,007 & 0,032 & 0,018 & 0,209 & 0,834 \\
& KUA & $-0,004$ & 0,040 & $-0,008$ & $-3,099$ & 0,017 \\
& ROA & $-0,020$ & 0,019 & $-0,091$ & $-3,606$ & 0,021 \\
& LEV & 0,157 & 0,108 & 0,120 & $-1,455$ & 0,148 \\
& 0,478 & 0,095 & 0,419 & 5,041 & 0,000 \\
\hline
\end{tabular}

Sumber: Olah data SPSS, 2022

Berdasarkan hasil output pada Tabel 12 dapat dijelaskan secara rinci sebagai berikut:

Variabel kepemilikan manajerial (KM) menujukkan nilai koefisien beta sebesar 0,14 dan mempunyai signifikansi sebesar 0,721 lebih besar dari 0,05 . Hal ini menunjukkan bahwa kepemilikan manajerial tidak berpengaruh signifikan terhadap manajemen laba, H1 ditolak.

Variabel kepemilikan institusional (KI) memperoleh nilai koefisien beta sebesar -0,017 dan nilai signifikansi sebesar 0,035 lebih kecil dari tingkat signifikansinya yaitu 0,05 sehingga $\mathrm{H} 2$ diterima. Hal ini menunjukkan bahwa kepemilikan institusional berpengaruh negatif signifikan terhadap manajemen laba.

Variabel kepemilikan asing (KA) memperoleh nilai koefisien beta sebesar 0,007 dan nilai signifikansi sebesar 0,834 lebih besar dari 0,05 sehingga H3 ditolak. Hal ini menujukkan bahwa kepemilikan asing tidak berpengaruh signifikan terhadap manajemen laba.

Variabel konsentrasi kepemilikan (KK) memperoleh nilai koefisien beta sebesar -0,004 dan nilai signifikansi sebesar 0,017 lebih besar dari 0,05 sehingga $\mathrm{H} 4$ diterima. Hal ini menujukkan bahwa konsentrasi kepemilikan berpengaruh negatif signifikan terhadap manajemen laba.

Variabel kualitas audit (KUA) memperoleh nilai koefisien beta sebesar -0,020 serta nilai signifikansi sebesar 0,021 lebih besar dari 0,05 sehingga H5 diterima. Hal ini menujukkan bahwa konsentrasi kepemilikan berpengaruh negatif signifikan terhadap manajemen laba.

Variabel kontrol profitabilitas memperoleh nilai koefisien beta 0,157 sebesar $-1,455$ serta nilai signifikansi ROA sebesar 0,148 lebih besar dari tingkat signifikansinya yaitu 0,05 . Hal ini 
menunjukkan bahwa profitabilitas sebagai variabel kontrol tidak dapat mempengaruhi manajemen laba.

Variabel kontrol leverage memperoleh nilai koefisien beta sebesar 0,478 dan nilai signifikansi LEV sebesar 0,000 lebih kecil dari tingkat signifikansinya yaitu 0,05 . Hal ini menunjukkan bahwa leverage sebagai variabel kontrol berpengaruh positif terhadap manajemen laba.

\section{PEMBAHASAN}

\section{Pengaruh kepemilikan manajerial terhadap manajemen laba}

Hasil pengujian secara parsial menunjukkan bahwa kepemilikan manajerial tidak berpengaruh signifikan terhadap manajemen laba. Hasil ini menjelaskan bahwa besar kecilnya jumlah kepemilikan manajerial yang dimiliki oleh dewan direksi, komisaris, direktur dan pihak manajemen perusahaan tidak dapat mempengaruhi manajemen laba. Hal ini dimungkinkan karena rata-rata proporsi kepemilikan saham manajerial yang rendah sebesar 0,16 atau $16 \%$ pada perusahaan manufaktur yang terdaftar di BEI periode 2017 sampai 2020 membuat manajer tidak mampu mengatasi konflik keagenan yang terjadi akibat adanya pemisahan kepemilikan dan kontrol. Faranita \& Darsono (2017) menyatakan bahwa rendahnya kepemilikan manajerial tidak mensejajarkan kepentingan antara pihak manajer dengan pemegang saham. Berbeda dengan peenelitian yang dilakukan oleh Tatar \& Sujani (|2021) yang menyatakan bahwa kepemilikan manajerial berpengaruh terhadap manajemen laba, semakin besar kepemilikan saham manajerial maka akan menurunkan manajemen laba. Hasil penelitian ini sejalan dengan Felicya \& Sutrisno (2020), Damayanti \& Kusumaningtias (2018), dan Antari et al., (2021) yang menyatakan bahwa kepemilikan manajerial tidak terdapat hubungan signifikan dan tidak dapat mempengaruhi manajemen laba.

\section{Pengaruh kepemilikan institusional terhadap manajemen laba}

Hasil pengujian secara parsial menunjukkan bahwa kepemilikan institusional berpengaruh negatif signifikan terhadap manajemen laba. Besarnya jumlah saham yang dimiliki oleh pihak institusi atau lembaga dengan rata-rata $54 \%$ pada perusahaan manufaktur di indonesia yang terdaftar di BEI periode 2017-2020 dapat dijadikan sebagai pengawasan yang efektif untuk mengurangi tindak oportunis manajemen dalam melakukan manajemen laba. Ini disebabkan karena besarnya kepemilikan saham yang semakin tinggi membuat pemegang saham memiliki akses informasi yang lebih dalam terhadap hal yang terjadi pada perusahaan yang dikelola oleh pihak manajemen (Mardianto, 2020). Penelitian ini sejalan dengan penelitian yang dilakukan oleh Yovianti \& Dermawan (2020), Cahyani \& Hendra (2020), Husni et al., (2021), dan Zubaidah et al., (2021) yang menyatakan bahwa kepemilikan institusional berpengaruh negatif signifikan terhadap manajemen laba. Semakin besar kepemilikan institusional, semakin kecil tingkat manajemen laba dalam perusahaan.

\section{Pengaruh kepemilikan asing terhadap manajemen laba}

Hasil pengujian secara parsial menunjukkan bahwa kepemilikan asing tidak berpengaruh signifikan terhadap manajemen laba. Investor asing sulit melakukan pengawasan secara langsung dalam aktivitas perusahaan karena keterbatasan jarak. Investor asing juga tidak memiliki kemampuan dalam mempengaruhi kebijakan yang ditentukan oleh pihak manajemen perusahaan karena rendahnya tingkat kontrol dalam struktur tata kelola perusahaan. Penelitian ini tidak sejalan dengan penelitian yang dilakukan oleh Nguyen et al., (2021) dan Kurawa et al., (2021) yang menyatakan bahwa kepemilikan asing berpengaruh negatif terhadap manajemen laba. Sebaliknya, penelitian ini sejalan dengan dengan penelitian yang dilakukan oleh Faranita \& Darsono, (2017), Maswadeh, (2018), dan Hadi \& Tifani (2020) yang menyatakan bahwa kepemilikan asing tidak berpengaruh terhadap manajemen laba.

\section{Pengaruh konsentrasi kepemilikan terhadap manajemen laba}

Hasil pengujian menunjukkan bahwa konsentrasi kepemilikan berpengaruh negatif signifikan terhadap manajemen laba. Besarnya konsentrasi kepemilikan individu atau satu pihak institusi 
dengan presentase rata-rata sebesar $49 \%$ pada penelitian ini membuat pemegang saham terkonsentrasi dapat menggunakan haknya untuk ikut serta dalam pengambilan keputusan pada suatu perusahaan dan mengawasi perilaku manajemen. Semakin besar tingkat kepemilikan terkonsentrasi pada suatu perusahaan dapat digunakan sebagai mekanisme kontrol terhadap perilaku manajer sehingga konflik dalam teori keagenan dapat dikurangi, sejalan dengan penelitian yang dilakukan oleh Maswadeh (2018) dan Nguyen et al., (2021) yang menyatakan bahwa konsentrasi kepemilikan berpengaruh negatif signifikan terhadap manajemen laba, yang menunjukkan semakin tingginya dominasi kepemilikan saham oleh pihak tertentu mampu mengurangi manajemen laba, begitu pula sebaliknya.

\section{Pengaruh kualitas audit terhadap manajemen laba}

Hasil pengujian secara parsial menunjukkan bahwa kualitas audit berpengaruh negatif signifikan terhadap manajemen laba. Hal ini menunjukkan bahwa semakin tinggi kualitas audit maka semakin rendah tingkat manajemen laba pada perusahaan. Kualitas audit dapat memperkuat opini dan keyakinan pada laporan keuangan pada perusahaan yang di terbitkan. Dengan adanya sikap independensi yang tinggi dan keterampilan auditor yang berasal dari KAP big four dapat digunakan sebagai alat deteksi manajemen laba pada laporan keuangan perusahaan. KAP big four akan memberikan jasa kualitas yang tinggi untuk mempertahankan reputasinya dan agar tidak kehilangan kepercayaan dari kliennya (Sari \& Susilowati, 2021). Hasil penelitian ini sejalan dengan penelitian yang dilakukan oleh Susanti \& Margareta (2019), Fandriani \& Tunjung (2019) dan Maulidah \& Santoso (2020) yang menyatakan bahwa kualitas audit berpengaruh negatif signifikan terhadap manajemen laba.

\section{Pengaruh variabel kontrol profitabilitas terhadap manajemen laba}

Hasil pengujian secara parsial menujukkan bahwa profitabilitas tidak mampu mempengaruhi manajemen laba. besar kecilnya tingkat profitabilitas tidak akan berdampak pada keinginan perusahaan dalam melakukan praktik manajemen laba. Hasil ini sejalan dengan penelitian yang dilakukan oleh Fandriani \& Tunjung (2019) dan (Agustia \& Suryani, 2018) yang menyatakan bahwa profitabilitas tidak mempunyai pengaruh dalam praktik manajemen laba, namun berbeda dengan hasil penelitian yang ditemukan oleh Kabeer \& Rafique (2018) dan Nguyen et al., (2021) yang menyimpulkan bahwa profitabilitas berpengaruh signifikan terhadap manajemen laba.

\section{Pengaruh variabel kontrol leverage terhadap manajemen laba}

Hasil pengujian secara parsial menujukkan bahwa leverage mempunyai pengaruh positif terhadap manajemen laba. semakin tinggi tingkat leverage semakin tinggi tingkat manajemen laba. Fandriani \& Tunjung (2019) menyatakan bahwa perusahaan akan melaporkan laba lebih tinggi dari yang sebenarnya karena tingkat rasio leverage yang tinggi membuat perusahaan kesulitan mendapatkan dana tambahan dari pihak eksternal. Untuk mendapatkan dana inilah yang akan membuat manajemen melakukan manajemen laba agar laba perusahaan menjadi bias. Hal ini sejalan dengan penelitian yang dilakukan Fandriani \& Tunjung (2019) dan Damayanti \& Kusumaningtias (2018) yang menyatakan bahwa leverage berpengaruh positif terhadap manajemen laba.

\section{KESIMPULAN}

Berdasarkan hasil pengujian dan pembahasan yang telah diuraikan, disimpulkan bahwa terdapat pengaruh negatif signifikan antara variabel kepemilikan institusional, konsentrasi kepemilikan dan kualitas audit terhadap manajemen laba. Variabel kepemilikan manajerial dan kepemilikan asing tidak berpengaruh signifikan terhadap manajemen laba. Dari dua variabel kontrol yang digunakan dalam penelitian ini hanya variabel leverage yang berpengaruh positif terhadap manajemen laba, sedangkan profitabilitas tidak dapat mempengaruhi manajemen laba. Nilai $R$-Squared sebesar $52 \%$ dapat dijelaskan oleh variabel-variabel yang terdapat dalam penelitian ini, sedangkan sisanya sebesar $48 \%$ dipengaruhi oleh faktor-faktor yang tidak dijelaskan dalam penelitian ini. Dalam mendeteksi manajemen laba peneliti hanya menggunakan variabel struktur kepemilikan, kualitas audit, profitabilitas dan leverage. Implikasi bagi peneliti selanjutnya, dapat menggunakan variabel lain seperti GCG, kebijakan deviden, arus kas bebas, dan umur 
perusahaan untuk mengetahui faktor-faktor yang dapat mempengaruhi manajemen laba yang tidak dijelaskan dalam penelitian ini, serta menggunakan objek penelitian selain sektor manufaktur seperti, sektor perbankan, sektor pertambangan, dan lain-lain.

\section{REFERENSI}

Agustia, Y. P., \& Suryani, E. (2018). Pengaruh Ukuran Perusahaan, Umur Perusahaan, Leverage, Dan Profitabiltas Terhadap Manajemen Laba. Jurnal Akuntansi Riset, 10(1), 63-74. https://doi.org/10.17509/jaset.v10i1.12571

Albert, \& Widyastuti, E. (2019). Analisis Pengaruh Kualitas Audit, Leverage, Dankepemilikan Manajerial Terhadap Manajemen Laba (Studi Empiris Pada Perusahaan Manufaktur Yang terdaftar Di Bursa Efek Indonesia tahun 2015--2017). Jurnal Akuntansi, Auditing Dan Keuangan, 16(1), 1-21. https://doi.org/10.25170/balance.v16i1.1284

Amalia, B. Y., \& Didik, M. (2017). Pengaruh Konsentrasi Kepemilikan, Kepemilikan Institusiona, Proporsi Dewan Komisaris Independen, Dan Frekuensi Rapat Komite Audit Terhadap Praktik Manajemen Laba. Diponegoro Journal Of Accounting, 6(3), 1-14.

Antari, N. L. M. W., Endina, I. D. M., \& Pramesti, I. G. A. A. (2021). Pengaruh Ukuran Perusahaan, Profitabilitas, Leverage Dan Kepemilikan Manajerial Terhadap Manajemen Laba Pada $\begin{array}{llll}\text { Perusahaan } \quad \text { Manufaktur. Jurnal } & \text { Karma, }\end{array}$ 810. https://doi.org/10.25134/jrka.v3i1.676

Cahyani, D., \& Hendra, K. (2020). Pengaruh Kepemilikan Institusional, Ukuran Perusahaan, Leverage Dan Tax Planning Terhadap Manajemen Laba. Akutansi Dan Keuangan, 11(2), 30-44. http://dx.doi.org/10.36448/jak.v11i2.1522

Damayanti, N. D., \& Kusumaningtias, R. (2018). Pengaruh Corporate Governance Terhadap Financial Distress Pada Sektor Perusahaan Jasa Infrastruktur, Utilitas Dan Transportasi Di Bursa Efek Indonesia Periode 2015-2017. Jurnal Akuntansi Unesa, 8(3).

Dwijayanti, N. M. A., \& Suryanawa, I. K. (2017). Pengaruh Asimetri Informasi, Kepemilikan Manajerial Dan Kepemilikan Institusional Pada Manajemen Laba. E-Jurnal Akuntansi, 18(1), 303-326.

Fandriani, V., \& Tunjung, H. (2019). Pengaruh Profitabilitas, Leverage, Ukuran Perusahaan Dan Kualitas Audit Terhadap Manajemen Laba. Jurnal Multiparadigma Akuntansi, 1(2), 505. http://dx.doi.org/10.24912/jpa.v1i2.5022

Faranita, W. A., \& Darsono. (2017). Pengaruh Leverage, Struktur Kepemilikan,Dan Kualitas Audit Terhadap Manajemen Laba. Diponegoro Journal Ofaccounting, 1(1).

Felicya, C, \& Sutrisno, P. (2020). Pengaruh Karakteristik Perusahaan, Struktur Kepemilikan Dan Kualitas Audit Terhadap Manajemen Laba. Jurnal Bisnis Dan Akuntansi, 22(1), 129-138. https://doi.org/10.34208/jba.v22i1.678

Giovani, M. (2017). Pengaruh Struktur Kepemilikan, Tata Kelola Perusahaan, Dankarakteristik Perusahaan Terhadap Manajemen Laba. Jurnal Akuntansi Bisnis, 15(2), 290-306. https://doi.org/10.24167/jab.v16i1.1367

Hadi, F. I., \& Tifani, S. (2020). Pengaruh Kualitas Audit Dan Auditor Switching Terhadap Manajemen Laba. Jurnal Bisnis Dan Akuntansi, 22(1), 95-104. https://doi.org/10.34208/jba.v22i1.620

Hasty, A. D., \& Herawaty, V. (2017). Pengaruh Struktur Kepemilikan, Leverage, Profitabilitas Dan Kebijakan Dividen Terhadap Manajemen Laba Dengan Kualitas Audit Sebagai Variabel 
Moderasi. Media Riset Akuntansi, Auditing \& Informas, 17(1), 1-10. http://dx.doi.org/10.25105/mraai.v17i1.2023

Indarti, M. G. K., \& Widiatmoko, J. (2021). The Effects Of Earnings Management And Audit quality On Cost Of Equity Capital: Empirical Evidence From Indonesia. Journal Of Asian $\begin{array}{llll}\text { finance,Economics } & \text { business, }\end{array}$ https://doi.org/10.13106/jafeb.2021.vol8.no4.0769

Laksmi, A. C. et, all (2018). The Effect Of Good Corporate Governance And Earnings Management To Corporate Social Responsibility Disclosure. Academy Of Accounting And Financial Studies Journal, 22(1), 1-16.

Mardianto. (2020). Analisis Pengaruh Struktur Kepemilikan, Ukuran Dan Pertumbuhan Perusahaan Terhadap Manajemen Laba Pada Perusahaan Bei Tahun 2014-2018. Journal of Applied Accounting And Taxation, 5(2), 222-232. https://doi.org/10.30871/jaat.v5i2.2305

Maswadeh, S. (2018). The Effect Of The Ownership Structure On Earnings Management Practices. Investment Management And Financial Innovations, 15(4), 48-60. DOI:10.21511/imfi.15(4).2018.04

Maulidah, R., \& Santoso, R. A. (2020). Pengaruh Kualitas Audit, Ukuran Perusahaan Dan Leverage Terhadap Manajemen Laba Pada Perusahaan Perbankan Yang Tercatat Dibursa Efek Indonesia Tahun 2016-2018. Jurnal Mahasiswa Manajemen, 1(1), 56-69. http://dx.doi.org/10.30587/mahasiswamanajemen.v1i01.1237

Obaidat, A. N. (2018). Income Smoothing Behavior At The Times Of Political Crises. International Journal Of Academic Research In Accounting, Finance And Management Sciences, 7(2), 113.

Pratiwi, R.H. (2019, April 30). Kronologi Kisruh Laporan Keuangan Garuda indonesia. CNN Indonesia. Diakses dari https://www.cnnindonesia.com/ekonomi/20190430174733-92390927/kronologi-kisruh-laporan-keuangan-garuda-indonesia

Sari, N. A., \& Susilowati, Y. (2021). Pengaruh Leverage, Ukuran Perusahaan, Profitabilitas, Kualitas Audit, Dan Komite Audit Terhadap Manajemen Laba. Jurnal Ilmiah Ase, 23(1), 43-52. https://doi.org/10.37470/1.23.1.176

Sulistyanto, H. S. (2018). Manajemen Laba: Teori Dan Model Empiris. Jakarta.Pt. Grasindo.

Susanti, L., \& Margareta, S. (2019). Pengaruh Kualitas Audit, Leverage Dan Ukuran Perusahaan Terhadap Manajemen Laba (Studi Empiris Pada Perusahaan Manufaktur Yang Terdaftar Di Bei Periode 2013- 2017),. J. Sains Manaj. Akunt, 11(1), 54-79. https://doi.org/10.37151/jsma.v11i1.15

Tarigan, M. O. T., \& Saragih, A. E. (2020). Pengaruh Kualitas Audit Terhadap Manajemen Laba Apada Perusahaan Perbankan Yang Terdaftar Di Bursa Efek Indonesia. Jurnal Riset Akutansi Dan Keuangan, 6(2), 185-206. https://doi.org/10.54367/jrak.v6i2.1057

Tatar, P. W. G., \& Sujani, E. (2021). Pengaruh Kepemilikan Manajerial, Employee Diff Dan Risiko Litigasi Terhadap Manajemen Laba Pada Perusahaan Manufaktur Di Indonesia. Jurnal Akutansi Profesi, 12(1), 10-20.

Wati, E., \& Gultom, T. O. R. (2021). He Impact Of Ownership Structure On Earnings Management: Evidence From The Indonesian Stock Exchange. Journal Of Accounting, Finance And Auditing Studies, 8(1), 152-175.

Widiatmoko, J., \& Indarti, M. G. K. (2018). Karateristik Perusahaan, Tipe Auditor Dan Konsentrasi 
Owner: Riset \& Jurnal Akuntansi

e-ISSN : 2548-9224 | p-ISSN : 2548-7507

Volume 6 Nomor 1, Januari 2022

Kepemilikan Saham Terhadap Pengungkapan Modal Intelektual. Jurnal Bisnis Dan Ekonomi, 25(1), 35-46.

Wijayanti, A., Wijayanti, A., \& Siddi, P. (2021). Pengaruh Perencanaan Pajak, Kualitas Audit Dan Gcg Terhadap Manajemen Laba. Urnal Ilmiah Mea (Manajemen, Ekonomi, \& Akuntansi), 5(2), 1816-1834. https://doi.org/10.31955/mea.vol5.iss2.pp1816-1834

Yovianti, L., \& Dermawan, E. S. (2020). Pengaruh Leverage, Profitabilitas, Ukuran Perusahaan, Dan Kepemilikan Institusional Terhadap Manajemen Laba. Jurnal Multiparadigma Akuntansi Tarumanagara, 2(1), 1799-1808. http://dx.doi.org/10.24912/jpa.v2i4.9376 